J. Perinat. Med. 15 (1987) 161

\section{Preconceptional diabetes control in insulin-dependent diabetes mellitus patients with continuous subcutaneous insulin infusion therapy}

\author{
Dov Dicker, Dov Feldberg, Moshe Karp ${ }^{1}$, Arie Yeshaya, Nurith Samuel, and \\ Jack A. Goldman
}

Department of Obstetrics and Gynecology, Golda Meir Medical Center, and ${ }^{1}$ The Institute of Pediatric and Adolescent Endocrinology, Division of Juvenile Diabetes, Beilinson Medical Center, Tel-Aviv University Medical School, Petah-Tikva, Israel

\section{Introduction}

Programs for maintaining glucose levels strictly within normal ranges have improved the outcome of pregnancies complicated by diabetes mellitus $[4,10,11]$. The diabetic pregnancy continues to present a significant risk for congenital malformations and neonatal morbidity [3, 14, $15,20,21]$. It seems that further improvement in the outcome of these pregnancies may be obtained if normal glucose levels are accomplished before conception, to reduce the incidence of congenital malformations [5, 15, 22] and throughout the pregnancy to lower the incidence of macrosomia $[3,23]$. This may be achieved with conventional two-dose or multiple insulin injections. Recently, continuous subcutaneous insulin infusion devices have been introduced to improve diabetic control in both the nonpregnant and pregnant diabetic patient $[8,18,24]$. The value of these insulin pumps must be critically assessed. Furthermore collaborative efforts of the diabetology team (diabetologist, dietitian, obstetrician, psychologist, social worker and nurse), as well as the patient, through self blood glucose monitoring (SBGM) is mandatory.

The purpose of this study was to critically compare and assess glucose control and the out- come of diabetic pregnancies, with preconceptional phase counseling, by means of continuous subcutaneous insulin infusion therapy to those receiving insulin injections.

\section{Material and methods}

Between the years 1981-1985 eighty-three juvenile onset insulin dependent diabetes mellitus (IDDM) pregnant women were treated at the High-Risk Obstetrical Outpatient Clinic of the Golda Meir Medical Center in association with the Institute of Pediatric and Adolescent Endocrinology, Division of Juvenile Diabetes, Beilinson Medical Center in Israel. Fifty-two patients contemplating pregnancy attended the preconceptional clinic and were consulted by a diabetology team (obstetrician, diabetologist, dietitian, psychologist, social worker and nurse). Two patients were advised against pregnancy, because of severe malignant retinopathy. They were permitted to conceive following laser therapy. Thirty-one patients who attended the clinic at different stages of pregnancy were deleted from the study. All patients completed their pregnancies and had delivered by the time of this report. In order to obtain optimal diabetes control before conception and to maintain nor- 
mal glucose levels throughout pregnancy the insulin need based on body weight was calculated $(0.6 \mathrm{U} / \mathrm{kg} / 24 \mathrm{~h}=$ pregestational; $0.7 \mathrm{U} /$ $\mathrm{kg} / 24 \mathrm{~h}=$ first trimester; $0.8 \mathrm{U} / \mathrm{kg} / 24 \mathrm{~h}=\mathrm{se}-$ cond trimester; $0.9 \mathrm{U} / \mathrm{kg} / 24 \mathrm{~h}=$ third trimester; $1.0 \mathrm{U} / \mathrm{kg} / 24 \mathrm{~h}=$ term). The total amount of insulin required was divided into insulin amounts that provided the basal needs and the bolus needs. Continuous subcutaneous insulin infusion pumps (CSIIP), Auto Syringe AS-G6, Medix 209/100 Insulin Pump, and recently the Nordisk Infuser were used in 18 women. Thirtyfour women received three to four injections a day of intermediate (NPH) and short-acting (regular) insulin. All patients were advised to adhere closely to their strict, prescribed diet, (American Diabetes Association diets $1800-2200 \mathrm{Kcal} /$ day), divided into three meals and two to three snacks. All patients performed self blood glucose monitoring $6-8$ times a day using glucose meters and charted the blood glucose levels. Hemoglobin $A_{1}$ was measured twice monthly by cation exchange column chromatography using microcolumn fast hemoglobin test system (Isolab, Akron, OHIO, USA). The normal range in our laboratory is $6.0-7.5$ percent.

After the glycosylated hemoglobin levels in the patients were below $8.5 \%$, which was the cutoff line for increased risk of malformations in MILLER's report [14], they were encouraged to conceive. In order to facilitate the very early diagnosis of pregnancy, patients were asked to measure basal body temperature through each menstrual cycle. The beta subunits of HCG was determined after a month had elapsed since the last menstrual period; if the test was negative it was repeated at weekly intervals while amenorrhea persisted.

Antepartum surveillance included: monthly ultrasound imaging for fetal growth or anomalies after 8 weeks' gestation [16], daily fetal movements count after 20-22 weeks' gestation [19],

Table I. Diabetes control in 52 IDDM pregnancies with preconceptional therapy.

\begin{tabular}{|c|c|c|c|c|c|c|c|c|}
\hline & Period & \multicolumn{2}{|c|}{$\begin{array}{l}\text { CSIIP } \\
(\mathrm{n}=18)\end{array}$} & \multicolumn{2}{|c|}{$\begin{array}{l}\text { IIT } \\
(\mathrm{n}=34)\end{array}$} & \multicolumn{2}{|c|}{$\begin{array}{l}\text { Normal pregnant } \\
(\mathrm{n}=20)\end{array}$} & $\mathrm{P}^{* *}$ \\
\hline 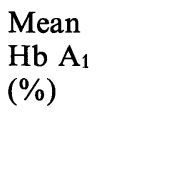 & $\begin{array}{l}\text { Initial visit } \\
\text { At conception } \\
\text { 1st trim. } \\
\text { 2nd trim. } \\
\text { 3rd trim. }\end{array}$ & & $\begin{array}{ll} \pm & 0.49 \\
\pm & 0.34 \\
\pm & 0.34 \\
\pm & 0.34 \\
\pm & 0.33\end{array}$ & $\begin{array}{r}10.5 \\
7.5 \\
7.6 \\
7.3 \\
7.3\end{array}$ & $\begin{array}{ll} \pm & 0.48 \\
\pm & 0.34 \\
\pm & 0.35 \\
\pm & 0.34 \\
\pm & 0.33\end{array}$ & & $\begin{array}{l} \pm 0.3 * \\
\pm 0.29 \\
\pm 0.29 \\
\pm 0.29 \\
\pm 0.29\end{array}$ & $\begin{array}{l}\text { N.S } \\
\text { N.S } \\
\text { N.S } \\
\text { N.S } \\
\text { N.S }\end{array}$ \\
\hline $\begin{array}{l}\text { Mean blood } \\
\text { glucose } \\
(\mathrm{mg} \%)\end{array}$ & $\begin{array}{l}\text { Initial visit } \\
\text { At conception } \\
\text { 1st trim. } \\
\text { 2nd trim. } \\
\text { 3rd trim. }\end{array}$ & $\begin{array}{l}179 \\
114 \\
124 \\
112 \\
109\end{array}$ & $\begin{array}{r} \pm 11.2 \\
\pm \quad 7.2 \\
\pm \quad 7.8 \\
\pm \quad 7.0 \\
\pm \quad 6.9\end{array}$ & $\begin{array}{l}175 \\
117 \\
128 \\
113 \\
110\end{array}$ & $\begin{array}{r} \pm 11.2 \\
\pm \quad 7.3 \\
\pm \quad 8.0 \\
\pm \quad 7.1 \\
\pm \quad 6.9\end{array}$ & $\begin{array}{l}96 \\
95 \\
91 \\
94 \\
98\end{array}$ & $\begin{array}{l} \pm 5.90^{*} \\
\pm 5.90 \\
\pm 5.60 \\
\pm 5.90 \\
\pm 6.10\end{array}$ & $\begin{array}{l}\text { N.S } \\
\text { N.S } \\
\text { N.S } \\
\text { N.S } \\
\text { N.S }\end{array}$ \\
\hline $\begin{array}{l}\text { Mean daily } \\
\text { insulin } \\
\text { dose (U) }\end{array}$ & $\begin{array}{l}\text { Initial visit } \\
\text { At conception } \\
\text { 1st trim. } \\
\text { 2nd trim. } \\
\text { 3rd trim. }\end{array}$ & $\begin{array}{l}39 \\
39 \\
44 \\
50 \\
62\end{array}$ & $\begin{array}{l} \pm 3 \\
\pm \quad 3 \\
\pm \quad 3 \\
\pm \quad 4 \\
\pm \quad 5\end{array}$ & $\begin{array}{l}42 \\
42 \\
48 \\
59 \\
76\end{array}$ & 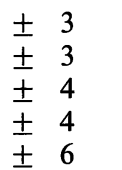 & & $\begin{array}{l}- \\
- \\
- \\
- \\
-\end{array}$ & $\begin{aligned} & \text { N.S } \\
& \text { N.S } \\
& \text { N.S } \\
&<0.05 \\
&<0.001\end{aligned}$ \\
\hline
\end{tabular}

* Normal non pregnant

** Statistical analysis by Students' $t$ test

Abbreviations used: CSIIP - Continuous Subcutaneous Insulin Infusion Pump

$$
\begin{aligned}
& \text { IIT - Intensified Insulin Therapy } \\
& \text { NS - Not Significant } \\
& \text { Trim - Trimester }
\end{aligned}
$$


and weekly fetal biophysical profile after 28 weeks' gestation [13]. Fetal lung maturity was evaluated by means of lung profile [12] and amniotic fluid microviscosity [1]. Timing and route of delivery were individualized according to maternal and fetal conditions.

\section{Results}

Table I presents diabetes control and insulin requirements in the 52 IDDM pregnant women treated prior to conception with CSIIP or with intensified insulin therapy.

In both groups mean blood glucose levels and mean $\mathrm{HbA}_{1}$ were elevated at the initial clinic visit prior to pregnancy, but normal $\mathrm{HbA}_{1}$ as well as physiologic blood glucose levels were achieved at conception and by the first trimester and maintained throughout the pregnancy. Nevertheless, in spite of the almost similar degree of improved diabetic control in both groups significantly lower mean daily insulin doses were required during the second $(50 \pm 4 \mathrm{U} ; \mathrm{p}<0.05)$ and third trimesters $(62 \pm 5 \mathrm{U} ; \mathrm{P}<0.001)$ of pregnancy by patients using infusion pumps in comparison to patients receiving intensified insulin therapy. Maternal information concerning the 52 gestations with preconceptional therapy is presented in table II. Patients using CSIIP were older, of higher parity and had a longer duration of diabetes as well as more frequent secondary complications. According to White's classification [25] 66.6\% of pump users were classified in groups $D-R$ whereas only $26.5 \%$ of the patients receiving insulin injections were in the same White's groups. The frequencies of pre-eclampsia and cesarean deliveries among pump users were higher than in patients managed with insulin injections.

In two patients treated with intensified insulin regimen hypoglycemia occured overnight in the $3^{\text {rd }}$ trimester. In one woman on the pump, temporary hypoglycemia occured in the first trimester shortly after the pump's installation. Neonatal data are presented in table III. Mean gestational age, mean birth weights, Apgar scores and neonatal complications were not significantly different in both groups. No malformations were detected in offspring of both groups.

Table II. Maternal information on 52 IDDM gestants.

\begin{tabular}{llr}
\hline Variable & $\begin{array}{l}\text { CSIIP } \\
(\mathrm{n}=18)\end{array}$ & $\begin{array}{l}\text { IIT } \\
(\mathrm{n}=34)\end{array}$ \\
\hline Mean maternal age (yr) & $26.1 \pm 7.1$ & $22.1 \pm 3.2$ \\
Mean duration of diabetes & $16.4 \pm 6.6$ & $12.6 \pm 5.4$ \\
White's classification & - & - \\
A & 1 & 8 \\
B & 5 & 17 \\
C & 7 & 8 \\
D & 1 & - \\
F & 4 & 1 \\
R & 2.3 & 1.9 \\
Parity & $38.3 \pm 0.5$ & $39.1 \pm 0.5$ \\
Mean duration of pregnancy (wks) & $13.4 \pm 3.8$ & $14.2 \pm 4.1$ \\
Mean weight gain (kg) & 22.2 & 8.8 \\
Pre-eclampsia (\%) & 44.4 & 23.5 \\
Cesarean section (\%) & & \\
\hline
\end{tabular}

Abbreviations used: CSIIP - Continuous Subcutaneous Insulin Infusion Pump

IIT - Intensified Insulin Therapy 
Table III. Neonatal data on 52 infants of IDDM mothers with preconceptional therapy.

\begin{tabular}{|c|c|c|c|}
\hline Variable & $\begin{array}{l}\text { CSIIP } \\
(\mathrm{n}=18)\end{array}$ & $\begin{array}{l}\text { IIT } \\
(\mathrm{n}=34)\end{array}$ & $\mathrm{P}^{*}$ \\
\hline Mean gestational age (wk) & $38.3 \pm 0.5$ & $39.1 \pm$ & NS \\
\hline Mean birth weight (gm) & $3284.5 \pm 233.2$ & $3346.1 \pm 237.6$ & NS \\
\hline Mean 1 minute Apgar & $8.1 \pm \quad 0.7$ & $8.4 \pm \quad 0.7$ & NS \\
\hline Mean 5 minutes Apgar & $9.0 \pm$ & $9.2 \pm$ & NS \\
\hline Hypoglycemia $[<30 \mathrm{mg}$ per $100 \mathrm{ml}](\%)$ & 11.1 & $11.8^{1}$ & NS \\
\hline Hypocalcemia $[<8 \mathrm{mg}$ per $100 \mathrm{ml}](\%)$ & 5.6 & 8.8 & NS \\
\hline Hyperbilirubinemia [ > $15 \mathrm{mg}$ per $100 \mathrm{ml}$ ] $(\%)$ & 11.1 & 11.8 & NS \\
\hline Respiratory distress syndrome (\%) & 5.6 & 5.8 & NS \\
\hline
\end{tabular}

* Statistical analysis by Students' $t$ test.

Abbreviations used: CSIIP - Continuous Subcutaneous Insulin Infusion Pump

IIT - Intensified Insulin Therapy

NS - Not Significant

\section{Comment}

The emerging evidence that congenital malformations in pregnancy complicated by diabetes may be linked to disturbances in maternal glucose metabolism during the period of embryogenesis $[2,9,15,20]$ provides a case for the institution of strict diabetic control prior to conception. Clinical evidence to support that position already has been documented $[5,14$, 22]. The need is underscored by the fact that organogenesis is completed by the 6th or 7th week of gestation in most of the structures in which diabetes related birth defects tend to occur [15], which is before the patient may know that she is pregnant and has not yet come to medical supervision. Normal glucose levels can be achieved in pregnant diabetic patients prior to conception and maintained throughout pregnancy either by conventional two-dose or multiple insulin injections $[4,6]$ as well as with the use of the newer insulin infusion pumps [8, $17,18]$. Optimal therapy necessitates individualization. Beyond the 28th week, when anti-insulin factors attain peak intensity, most pregnant women in our Center obtain additional multiple (regular) insulin injections. In fact, the precise doses are adjusted to achieve good metabolic control. Moreover, we recommend CSIIP in selected, well motivated patients with severe diabetes contemplating pregnancy.
Our findings reflect the fact that successful glucose control can be obtained in pregnant diabetic patients prior to and throughout pregnancy, with the use of CSIIP as well as with intensified insulin therapy. The cost/benefit ratio is, in favor of IIT because it is cheaper to provide. It is necessary to note that patients with intensified insulin therapy required significantly higher doses of insulin during the second and third trimester of pregnancy in comparison to pump users. Indeed, excessive insulin doses becomes a concern since the consequences of excessive insulin may compromise both the mother and the fetus with hypoglycemia and by suppressing the levels of alternate fetal fuels, such as plasma beta hydroxybutyrate [7]. In fact, patients on intensified insulin therapy in this study had occasional overnight hypoglycemia, while pump users achieved normal glucose levels without overt insulin administration.

Insulin pumps were advantageous during intercurrent illness, as adjustment to rapid changes in insulin requirements could be made easily and effectively, even in the home environment. Patients accepted the pump system well; mainly the smaller, compact devices were more acceptable. No serious complications resulted from the continuous subcutaneous infusion system during this study. One pump underwent a mechanical "run away", and insulin administra- 
tion was discontinued temporarily. The patient was given I. V. glucose $10 \%$ and extra snacks until normal glucose levels were achieved when normal insulin/diet schedule was resumed.

In spite of the successful CSIIP therapy in this series it can not be recommended for every diabetic patient prior to and during gestation, and it should remain an investigational tool. Specific selective criteria for well motivated patients need to be established. Although pump users in this group had a higher rate of preeclampsia which contributed in part to the higher cesarean section rates, we consider that more of these patients had more severe diabetes $(66 \%$ - White's class D-R).

\section{Summary}

Preconceptional diabetes management is an important prerequisite for pregnancy planning and its value has been well-documented. Glucose control and the outcome of pregnancy, managed in the preconceptional period, with continuous subcutaneous insulin infusion therapy to those receiving insulin injections are compared.

Fifty-two juvenile onset insulin dependent diabetic women contemplating pregnancy were regularly consulted by a diabetology team starting at least two months before conception. Glucose control was achieved by continuous subcutaneous insulin infusion pumps (CSIIP) in 18 patients, and 34 women received intensive
Our data emphasize the improved metabolic control achieved by either technique in this series. We feel that establishment of tight metabolic control before conception and during pregnancy contributed to better control of diabetes, particularly at the crucial time of conception. The reduction of congenital malformation rates due to preconceptional diabetic control must further be studied and proven.

We must conclude on the basis of this study, that in spite of the advantageous use of CSIIP in selected cases, the disadvantages of these devices, as well as good results achieved with IIT, favor the use of the latter in the treatment of the pregnant diabetic.

insulin therapy (IIT). In both groups, normal glucose levels and normal $\mathrm{HbA}_{1}$ were achieved at conception, maintained during the period of organogenesis and throughout pregnancy.

In view of the fact that perinatal results, such as the occurrence of malformations, mean gestational age, mean birth weight and neonatal complications were not significantly different in both groups, we believe that both methods are equally effective. Consequently, the less costly and yet effective IIT may be the method of choice, while the more expensive pump should be used mainly in selected cases.

Keywords: Diabetes mellitus, diabetic pregnancy, insulin infusion pump, preconceptional diabetes control, pregnancy planning in diabetics.

\section{Zusammenfassung}

Diabeteseinstellung vor der Konzeption bei insulinabhängigen Patientinnen mit kontinuierlicher subkutaner Insulininfusion

Die Bedeutung der Diabeteseinstellung vor einer geplanten Schwangerschaft ist bekannt und nachgewiesen. Bereits vor der Konzeption erhielten die Frauen entweder eine kontinuierliche subkutane Insulininfusionstherapie oder Insulininjektionen in üblicher Weise. Wir haben diese beiden Kollektive hinsichtlich ihrer Blutzuckerspiegel und der Schwangerschaftsverläufe miteinander verglichen.

50 Frauen mit insulinabhängigem juvenilen Diabetes, die eine Schwangerschaft planten, wurden mindestens 2 Monate vor Konzeption von Diabetologen beraten. Bei 18 Patientinnen wurde der Glukosespiegel mit subkutanen Insulininfusionen über eine Pumpe eingestellt, 34
Patientinnen erhielten Insulingaben in üblicher Form, wurden aber strenger eingestellt. In beiden Gruppen

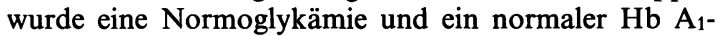
Wert bei Konzeption erreicht, die auch in der Phase der Organogenese und über die gesamte Schwangerschaft aufrechterhalten werden konnten.

Im Hinblick auf verschiedene perinatale Parameter wie Häufigkeit von Mißbildungen, durchschnittliches Gestationsalter und Geburtsgewicht sowie neonatale Komplikationen gab es zwischen beiden Gruppen keine signifikanten Unterschiede, so daß wir glauben, daß beide Methoden gleich effektiv sind. Die weniger kostenintensive und dennoch effektive strenge Einstellung mit Insulininjektionen sollte die Methode der Wahl sein, während die teure Insulinpumpe hauptsächlich ausgewählten Fällen vorbehalten sein soll.

Schlüsselwörter: Diabeteseinstellung vor Konzeption, Diabetes mellitus, Diabetes und Schwangerschaft, Insulininfusionspumpe, Schwangerschaftsplanung bei Diabetes. 


\section{Résumé}

Contrôle du diabète avant la conception chez les patientes insulino-dépendantes par perfusion continue d'Insuline sous-cutanée

L'équilibre du diabète avant la conception est une nécessité importante pour la plannification de la grossesse et sa valeur est bien documentée. On compare le contrôle glycémique et le devenir de la grossesse chez des patientes prises en charge à la période pré-conceptionnelle à l'aide de perfusion continue d'Insuline sous-cutanée à ceux de patientes traitées par injections d'Insuline.

Cinquante deux femmes atteintes d'un diabète insulinodépendant à début juvénile, souhaitant une grossesse ont été suivies régulièrement par une équipe diabétologique en débutant au moins deux mois avant la conception. Chez 18 patientes, le contrôle glycémique était réalisé à l'aide de pompes à perfusion continue d'Insuline sous-cutanée (CSIIP), chez 34 de contrôle était réalisé par une augmentation de l'insulinothérapie (ITT). Dans les deux groupes, à la conception une glycémie normale et une $\mathrm{Hb}_{\mathrm{A} 1}$ normale étaient obtenues et maintenues pendant toute la période d'organogénèse et tout au long de la grossesse.

Nous pensons que les 2 méthodes sont équivalentes dans la mesure où les résultats périnataux, comme le taux de malformations, l'âge gestationnel moyen, le poid de naissance moyen et les complications néonatales ne sont pas différents de façon significative dans les deux groupes.

Par conséquent, la méthode de choix est l'ITT qui est la plus économique et néanmoins aussi efficace, alors que les pompes, beaucoup plus couteuses, devraient être réservées principalement à des cas sélectionnés.

Mots-clés: Contrôle pré-conceptionnel du diabète, diabète sucré, grossesse chez la diabétique, plannification des grossesses chez la diabétique, pompe à perfusion d'Insuline.

\section{References}

[1] Barkai G, S Mashiach, D Lanzer, Z Kayam, M BRISH, B GoldMAN: Determination of fetal lung maturity from amniotic fluid microviscosity in high risk pregnancy. Obstet Gynecol 59 (1982) 615

[2] Cockroft DL, M Freinkel, LS Phillips, GE SHAMBAUGH: Metabolic factors affecting organogenesis in diabetic pregnancy. Clin Res 23 (1981) $577 \mathrm{~A}$

[3] Enzi G, EM Inelmen, F Caretta, F Villani, V ZANARDO, $F$ DeBIASI: Development of adipose tissue in newborns of gestational-diabetic and insulin-dependent diabetic mothers. Diabetes 29 (1980) 100

[4] Freinkel N, BE Metzger, JM Potter: Pregnancy in diabetes. In: ElLENBERG M, H RIFKIN (eds): Diabetes Mellitus Theory and Practice, pp 689-714. Medical Examination Publishing, New York 1983

[5] Fuhrmann K, H Reiher, K Semmler, F Fisher, M Fisher, E GLOCKNER: Prevention of congenital malformations in infants of insulin dependent diabetic mothers. Diabetes Care 6 (1983) 219

[6] GABBE SG: Medical complications of pregnancy management of diabetes in pregnancy, six decades of experience. In: PITKIN RM, FJ ZLATNIK (eds): Year Book of Obstetrics and Gynecology, Part I, pp 37-49. Year Book, Chicago 1980

[7] GIRARD JR: Metabolic fuels of the fetus. Isr J Med Sci 11 (1975) 591

[8] Hertz RH, KC King, SC Kalhan: Management of third trimester diabetic pregnancies with the use of continuous subcutaneous insulin infusion therapy: A pilot study. Am J Obstet Gynecol 149 (1984) 256
[9] HORTON WE JR, TW SADLER: Effects of maternal diabetes on early embryogenesis: alterations in morphogenesis produced by the ketone body, betahydroxybutyrate. Diabetes 32 (1983) 610

[10] Jovanovic L, M Druzin, CM Peterson: Effect of euglycemia on the outcome of pregnancy in insulindependent diabetic women as compared with normal control subjects. Am J Med 71 (1981) 921

[11] Kitzmiller JL, JP Cloherty, MD Younger, A TABATABII, SB RotCHILD, I SOSENKo, MF EPSTEIN, S SINGH, RK NeFF: Diabetic pregnancy and perinatal morbidity. Am J Obstet 131 (1978) 560

[12] Kulovich MV, L GLUCK: The lung profile II. Complicated pregnancy. Am J Obstet Gynecol 135 (1979) 64

[13] Manning FA, LC Platt, L Sipos: Antepartum fetal evaluation: Development of a fetal biophysical profile. Am J Obstet Gynecol 136 (1980) 787

[14] Miller E, JW Hare, JP Cloherty, PJ DunN, RE Gleason, JS SoELDNER, JL KITZMILleR: Elevated maternal HbA1c in early pregnancy and major congenital anomalies in infants of diabetic mothers. $\mathrm{N}$ Engl J Med 304 (1981) 1331

[15] Mills JL, L BaKer, AS Goldman: Malformations in infants of diabetic mothers occur before the seventh gestational week. Implications for treatment. Diabetes 28 (1979) 292

[16] Pedersen JF, L Molsted-Pedersen: Early fetal growth delay detected by ultrasound marks increased risk of congenital malformations in diabetic pregnancy. Br Med J 283 (1981) 2691

[17] Potter JM, JPD Reckless, DR Cullen: Subcutaneous continuous insulin infusion and control of blood glucose concentrations in diabetics in third trimester of pregnancy. Br Med J 1 (1980) 1099 
[18] Rudolf MCJ, DR Coustan, RS Sherwin, SE BATES, P FELIG, M GeNEL, WV TAMBORLANE: Efficacy of the insulin pump in the home treatment of pregnant diabetics. Diabetes 30 (1981) 891

[19] Sadovsky E, H JAFFe, WZ PolishuK: Fetal movement monitoring in normal and pathological pregnancies. Int J Gynecol Obstet 12 (1974) 75

[20] Soler NG, CH Walsh, JM Malins: Congenital malformations in infants of diabetic mothers. Q J Med 178 (1976) 303

[21] Soler NG, SM Soler, JM Malins: Neonatal morbidity among infants of diabetic mothers. Diabetes Care 1 (1978) 340

[22] Steel JM, ED Johnstone, AF SMith, LJP DunCAN: Five years experience of a "prepregnancy" clinic for insulin dependent diabetics. Br Med J 285 (1982) 353
[23] Susa JB, C Neave, P Sehgal, DB Singer, WP ZELLER, R SCHWARTZ: Chronic hyperinsulinemia in the fetal Rhesus monkey: effects of physiologic hyperinsulinemia on fetal growth and composition. Diabetes 33 (1984) 656

[24] Tamborlane WV, RS Sherwin, M Genel, P Felig: Reduction to normal of plasma glucose in juvenile diabetes by subcutaneous administration of insulin with a portable infusion pump. N Engl J Med 300 (1979) 573

[25] WhITE P: Classification of obstetric diabetes. Am J Obstet Gynecol 130 (1978) 228

Received February 14, 1986. Revised July 17, 1986. Accepted August 25, 1986.

Jack A. Goldman, M. D.

Professor and Chief

Department of Obstetrics and Gynecology

Golda Meir Medical Center (Hasharon Hospital)

Petah-Tikva, Israel 49372 


\section{Truce Element}

Analytical Chemistry in Medicine and Biology

\section{Volume 4}

Proceedings of the Fourth International Workshop

Neuherberg, Federal Republic of Germany, April 1986

Editors P. Brätter P. Schramel

1987. $17 \mathrm{~cm} \times 24 \mathrm{~cm}$. XIII, 630 pages. Numerous illustrations.

Cloth DM 295,-; approx. US \$155.50 ISBN 3110109050

The proceedings of the 4th Workshop deal with new developments in the trace element analysis of biological materials as well as with current problems in trace element metabolism, nutrition, diagnosis and the therapy of trace element related diseases.

Contents (Main Chapters)

Models for Trace Element Metabolism - Trace Element in Nutrition - Trace Element Interactions - Trace Element Analysis of Body Fluids and Tissue Samples - Significance of Trace Elements in Medicine - List of Participants . Author Index · Subject Index.

Also available

Trace Element Analytical Chemistry in Medicine and Biology

Volume 1: 1980. XV, 851 pages. DM 180,-; approx. US $\$ 95.00$

Volume 2: 1983. XX, 1189 pages. DM 280,-; approx. US $\$ 147.50$

Volume 3: 1984. XVI, 763 pages. DM 240,-; approx. US $\$ 126.50$

Prices are subject to change without notice

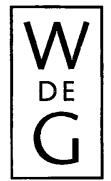

de Gruyter · Berlin · New York 